\title{
Effect of Use of Aluminum Foil Blanket Against Increased Body Temperature in Patients Hypothermia after Spinal Anesthesia in the Operation Room of the Sele Be Solu Hospital, Sorong West Papua
}

\author{
Nurul Kartika Sari ${ }^{1}$, Yogik SetiaAnggreini ${ }^{1}$, Rolyn Djamanmona ${ }^{1}$, Anwar Mallongi ${ }^{2}$, Rickar Julio Hulukiti ${ }^{1}$ \\ ${ }^{1}$ Lecturers of Poltekkes Kemenkes Sorong, ${ }^{2}$ Professor of Environmental Health Department, \\ Faculty of Public Health, Hasanuddin University, Makassar
}

\begin{abstract}
Local, general, and regional anesthesia is complex actions or events that cannot be separated from elective or emergency surgery. Anesthesia affects the three thermoregulatory elements consisting of afferent input elements, signal regulation in the central region, and also the efferent response which can lead to hypothermia. This study aims to determine the effect of the use of aluminum foil blankets on increasing body temperature in hypothermia patients after spinal anesthesia. This study uses a Pre-Experimental study design with a PrePost Test Only Design approach. Sampling in this study used a purposive sampling technique. 12 samples were given the intervention to use aluminum foil blankets. Analysis of data using the Shapiro-Wilk test, Homogeneity of Lavene Test, and Paired sample T-Test. The results of statistical tests using the Paired Sample T-Test obtained a p-value of less than $0.05(<0.05)$, namely $p=0.000$. There is an influence of the use of aluminum foil blankets to increase body temperature in hypothermia patients after spinal anesthesia.
\end{abstract}

Keywords: Hypothermia, Aluminum Foil Blanket, Post Spinal Anesthesia.

\section{Introduction}

Local, general, and regional anesthesia is complex actions or events that cannot be separated from elective or emergency surgery ${ }^{1}$. All surgical actions or operating procedures that have a risk of impaired integrity or completeness of the body can even be a threat to the patient's life. Other problems can also arise related, anesthesia techniques, patient positions, medicines, blood components, room readiness for patients, room temperature and humidity, electrical equipment hazards, potential contamination, and psychosocial is noise, negligible taste, and unnecessary conversation ${ }^{2}$. In the first hour after spinal anesthesia administration will

\footnotetext{
Corresponding Author:

Nurul Kartika Sari

Lecturers of Poltekkes Kemenkes Sorong

e-mail: ns.nurulkartikasari@gmail.com, yogik.

setia89@gmail.com
}

occur decreased shivering threshold of about $1^{\circ} \mathrm{c}$ up to $2^{\circ} \mathrm{c}$. Anesthesia affects all three thermoregulation elements consisting of Aferen inputs, signal settings in the central area, and also the efferent response otherwise, it can also eliminate the adaptation process as well as interfere with the mechanism of lipid or skin physiology in thermoregulation function. This resulted in the patient having hypothermia ${ }^{3}$.

The Post-operative hypothermia incidence rate can be said quite highly. The year 2015 at the Brazilian Hospital Hypothermia event number post operations as much as 98 (93.3\%) Patients from 105 patients experienced Hypothermia postoperative ${ }^{4}$. The year 2019 $54(69.2 \%)$ From 78 experienced hypothermia in the post-anesthesia recovery chamber ${ }^{5}$. In the year 2017 at the RSUD Wates the hypothermia incidence rate as much as $36(65.5 \%)$ Of the 55 patients who post operations ${ }^{6}$. At the Sele Be Solu Hospital the hypothermia incidence is 8 out of 10 patients with an average temperature of $35.8^{\circ} \mathrm{c}$. Preliminary study interviews were 38 patients with postoperatively in the Sele Be Solu Hospital 
operating room with several post-operative patients with anesthesia indicates that they often experience cold (hypothermia) while being in the operating room and recovery room.

Hypothermia is classified as induction hypothermia or an accident and secondary hypothermia. An induction or accident hypothermic is caused by low environmental temperature management, dose medications, and certain diseases such as myxedema and hypopituitarism. While secondary hypothermia can occur in surgical patients and cause by several factors such as, due to low temperature in the operating room, infusion with cold liquids, use of inhaled anesthetic techniques with cold gas, cavities or open wounds, muscle activity that decreases during anesthesia, advanced age or the type of medication used during anesthesia.

The occurrence of hypothermia will activate shivering mechanisms as to increase metabolism, muscle activity above normal levels to produce heat, also increases two to three times the consumption of oxygen and $\mathrm{CO}_{2}$ production. Complications in the form of shivering in this case, occur due to skeletal muscle contractions or tremors in the face, chin, and extremities for \pm 15 minutes accompanied by a process of hypothermia and vasodilation. This condition can make things worse than pain, and disrupt the observation of the patient's condition and physical comfort ${ }^{7}$.

The treatment of hypothermia that can be undertaken involves non-pharmacological and pharmacological action. Non-pharmacological therapy techniques can be performed by providing warm blankets, regulating adequate ambient temperatures, as well as using fluid warmers for transfusion and other liquids ${ }^{8-12}$. Interventions to lower the state of postoperative chills can be with active or externally active internal heating. Ambient temperature in the room is recovered, wet dresses and blankets are removed and replaced with a dry because it can enlarge heat loss, intravenous fluid, and irrigation are heated to $37^{\circ} \mathrm{c}$.

Regardless of the method used to warm the patient, the reforesting must be carried out gradually and not quickly ${ }^{7}$. The use of an aluminum foil blanket is a method to stabilize body temperature. Clarissa's research results, proved that the treatment of hypothermia can be solved by passive warming intervention. The results of the research Marlinda, et al., ${ }^{13}$ proved that the use of warm blankets that are coated in an aluminum foil is more effective than ordinary warm blanket use in the return speed of post-operation body temperature.

Based on the explanation above, the authors are interested to research on the effect of the use of aluminum foil blanket against an increase in body temperature in patients after spinal anesthesia in Sele Be Solu Hospital.

\section{Materials and Method}

This type of research uses a Pre-experimental study design with a Pre-PostTest Only Design approach. Pre experiments are experiments that have treatment, impact measurement, union experiment but don't use assignments randomly to create comparisons to conclude changes that are caused by treatment. Sampling in this study used purposive sampling techniques. The total sample in this study amounted to 12 people. The data collected includes the characteristics of respondents based on age, gender, and body temperature pre and postintervention using an observation sheet. Data retrieval is carried out at the Sele Be Solu Hospital Sorong for one day while observing the principles of beneficence ethics, respect for human dignity, and justice. Analysis of data using the Shapiro-Wilk test, Homogeneity of Lavene Test, and Paired sample T-Test.

\section{Results}

The collection of data on this research has been conducted at the Sele Be Solu Hospital in Sorong for 8 days on 18-25 March 2020. Characteristic data includes age and gender. The average age of respondents was $42.92( \pm 9700)$. Male-gender respondents numbered four $(33.3 \%)$ Female gender amounted to $8(66.7 \%)$. Variable temperature data using the Paired test sample $\mathrm{T}$-Test indicates there is a significant influence on the increase in body temperature after the intervention $(\mathrm{P}=$ $0.000)$.

Table 1: Results analysis of Pre-Test and Post-Test use of Aluminium Foil blanket against an increase in body temperature in patients with hypothermia after spinal anesthesia

\begin{tabular}{|l|c|c|c|c|}
\hline Temperature & Mean \pm SD & Min & Max & p \\
\cline { 1 - 4 } Pre- Test & $34.6 \pm 0.5444$ & 33.7 & 35.8 & \multirow{2}{*}{$0.000^{*}$} \\
\cline { 1 - 4 } Post-Test & $36.7 \pm 0.1055$ & 36.5 & 36.9 & \\
\hline
\end{tabular}

*Significant at $\alpha=<0.05$ 


\section{DISCUSSION}

Based on the results of the study showed the age characteristics of the most respondents were at vulnerable age 46-55 which amounted to six respondents with a presentation of $50 \%$ and the lowest was at the age of 16-25 which amounted to one respondent with a presentation of $8.3 \%$. It is shown that the elderly are one of the factors affecting hypothermia post-anesthesia. This can occur because when a person enters the age of the elderly, the state of cells in the body will change. The thermoregulation system will be disrupted so the elderly are more likely to experience loss of body temperature. Anesthesia that is done in elderly patients can lead to a shift in the thermoregulation threshold with greater degrees compared to young patients ${ }^{14}$.

This research is in line with the research conducted by Amila Hanifa, ${ }^{6}$ which suggests that patients who often experience hypothermia are at the age range of 46-60 years with a total of $21(38.2 \%)$ of 55 patients. Another research in line is the research conducted by Harahap, indicating that the incidence of hypothermia in the elderly reached $113(87.6 \%)$ of 129 patients. While the research is not in line with this study, the research conducted by Clarissa, ${ }^{15}$ showed that elderly patients who experienced hypothermia only 20 (19\%) of 105 patients.

The results showed that most respondents were female genders of 8 respondents with a $66.7 \%$ presentation. This suggests that gender is one of the factors affecting hypothermia post-anesthesia. Men and women have a difference in body temperature consistency. In general, women have a larger body temperature fluctuations than men. This happens because of the effect of the hormonal production of progesterone hormones. If the hormone progesterone decreases, then the body temperature decreases a few degrees below the normal limit. ${ }^{14}$.

This research is in line with research conducted by Mendonc, ${ }^{16}$ which shows the number of hypothermia in female gender reaches $62(79.48 \%)$ of 78 patients. The results of this research is also in line with the research conducted by Harahap, ${ }^{14}$ explained that more hypothermia number in women is $51.2 \%$. The results of other studies in line with this study were research conducted by Clarissa, ${ }^{17}$ explaining that female patients experiencing hypothermia reached $73(69.5 \%)$ of 105 patients.
The characteristic of an aluminum foil is strong, lightweight, heat resistant, and almost airtight, which doesn't contain magnets ${ }^{18}$. An aluminum foil blanket is a method used to increase body temperature in preterm hypothermia due to an air resistant aluminum foil. Aluminum foil blankets can also be used to cope with and increase body temperature in patients with hypothermia due to the environment. Patients who experience hypothermia are caused by too cold room temperature, infusion with cold liquids, cold inhalation, decreased muscle activity, or the influence of drugs used such as vasodilators, spinal and generalized anesthesia ${ }^{19-22}$.

In the first hour after spinal anesthesia administration will occur decreased shivering threshold of about $1^{\circ} \mathrm{c}$ up to $2^{\circ} \mathrm{c}$. Anesthesia affects all three thermoregulation elements consisting of afferent input elements, signal settings in the central area as well as the effusive response otherwise, it can also eliminate the adaptation process as well as disrupt the mechanism of fat or skin physiology in thermoregulation function. At the time of administration of anesthesia spinal body undergo vasodilation. This is what makes the body's metabolism increased so that the body experiences a decrease in temperature ${ }^{3}$.

The use of heat-resistant aluminum foil covers and air can make the body vasoconstriction because the blanket of aluminum foil minimizes the body or skin to interact with air or the stimulus resulting in hypothermia. When the body does not get the stimulus, the body will undergo vasoconstriction due to heat restrained with an aluminum foil blanket. So slowly the body temperature will begin to increase to normal body temperature ${ }^{3}$

Research conducted by Marlinda, Ramdani, and Mariana ${ }^{19}$, concluded that there is an influence on the blanket of warm coated aluminum foil blanket to increase the body temperature of the patient's hypothermia postSC. Another research result that can support this research is research conducted by Jessica Watson ${ }^{3}$ concluded that the blanket of aluminum foil or warm blanket can also handle the problem of postoperative hypothermia.

This research is in line with previous related studies where there is an influence on the use of aluminum foil blankets against increased body temperature in patients with hypothermia after spinal anesthesia. The use of aluminum blankets within 10 minutes can make the blood vessels that have been vasodilation transformed into vasoconstriction. So that the blanket aluminum foil can be used to overcome the problem of post-anesthesia hypothermia. 


\section{Conclusion}

Aluminum foil blankets are effective in increasing the body temperature post-spinal anesthesia. For nursing services, researchers recommend the blanket aluminum foil intervention can be used as standard operational procedures against hypothermia after spinal anesthesia. For further researchers to examine the factors affecting hypothermia post-anesthesia such as old surgery, body mass index, and anesthesia type. Further researchers can also add samples and compare blankets of aluminum foil to the increase in the body temperature of post-spinal anesthesia.

Ethical Clearance: Taken from Poltekkes Kemenkes Sorongethical committee

Source of Funding: Poltekkes Kemenkes Sorong

\section{Conflict of Interest: Nil}

\section{References}

1. Sjamsuhidajat, Buku Ajar Ilmu Bedah, Salemba Medika, Jakarta: EGC2010

2. Arif Muttaqin, Asuhan Keperawatan Perioperatif: Konsep, Proses, dan Aplikasi, Salemba Medika, Jakarta; EGC2016,

3. Watson, Jessica "Inadvertent postoperative hypothermia prevention: Passive versus active warming method," Journal of Perioperative Nursing: 2018; Vol. 31 : Iss. 1, Article 4.Available at: https://doi.org/10.26550/2209-1092.1025

4. Beatriz, Prado, Barichel, Pires, Haas, Barbosa, 'Occurrence and factors associated with hypothermia during elective abdominal surgery', Acta Paul Enferm, 2015; vol 28, hh. 475-481

5. Avellans M.L, A. Ricart, J. Botella, F. Mangelle, I. Soteras, T. Verres, M. Vidal..Management of Severe Accidental Hypothermia. Medicina Intesiva. 2011

6. Amila Hanifa, The Correlation Of Hypothermia With Recovery Time Post General Anesthesia In The Recovery Room Ofrsud WATES. PoliteknikKementerian Kesehatan. hh2017; 1-8

7. Brunner \& Suddarth, Medical Surgical Nursing, Lippincont-Raven Publishers, Philadelphia; Lippincont-Raven Publishers.2014,

8. Mallongi, A., Daud, A., Ishak, H., La Ane, R., Birawida, A.B., Ibrahim, E., Selomo, M., Rahman, S.A. Clean water treatment technology with an up- flow slow sand filtration system from a well water source in the tallo district of Makassar. Journal of Environmental Science and Technology, 2017; Volume 10, Issue 1, Pages 44-48

9. Hasmi, Mallongi, A. Health risk analysis of lead exposure from fish consumption among communities along Youtefa Gulf, Jayapura. Pakistan Journal of Nutrition 2016; Volume 15, Issue 10, 15 September Pages 929-935

10. Kayame, R., Mallongi, A. Relationships between smoking habits and the hypertension occurrence among the adults of communities in paniai regency, Papua Indonesia. Indian Journal of Public Health Research and Development 2018; Volume 9, Issue 1, Pages 332-336

11. EndahYani, R.W., Mallongi, A., Andarini, S., Prijatmoko, D., Dewanti, I.R. The effect of zinc saliva on the toddlers' nutritional status. Journal of International Dental and Medical Research, 2016, Volume 9, Issue 1, Pages 29-32

12. Birawida, A.B., Selomo, M., Mallongi, A. Potential hazards from hygiene, sanitation and bacterium of refill drinking water at BarrangLompo island (water and food safety perspective) IOP Conference Series: Earth and Environmental Science 2018; Volume 157, Issue 1, Article number 012034

13. Marlinda, Ramdani, Mariana, 'Perbandingan Selimut Hangat Dengan Selimut Hangat Dilapisi Selimut Aluminium Foil Terhadap Kecepatan Kembalinya Suhu Tubuh Normal PadaPasien HipotermipostSc (Sectio Caesar) Di Recovery Room Rsud Ulin Banjarmasin', Implikasi Perawatan Paliatifpada Bidang Kesehatan, 2017; vol 8, hh. 206-212

14. Harahap, A. M. Angka Kejadian Hipotermiadan Lama Perawatan di IBS pada Pasien Geriatri Pasca Operasi Elektif Bulan Oktober 2011- Maret 2012 di RumahSakit Dr. Hasan Sadikin Bandung. Jurnal Anestesia Perioperatif. 2014; Volume 2(1) No:3644. Fakultas Kedokteran Universitas Padjajaran

15. Clarissa Shaw, Steelman, DeBerg, Schweizer, 'Effectiveness of active and passive warming for the prevention of inadvertent hypothermia in patients receiving neuraxial anesthesia: A systematic review and meta-analysis of randomized controlled trials', Author Manuscript, 2018; vol 1, hh. 1-34

16. Mendonc, Lucena, Quirino, Govêia, Nunes, 'Fatores de riscoparahipotermiapós- 
operatóriaemsala de recuperac,ãopós-anestésica: estudopilotoprospectivo de prognóstico', Revista Brasileira De Anestesiologi, 2019; vol 69, hh. 122130

17. Clarissa Shaw, Steelman, DeBerg, Schweizer, 'Effectiveness of active and passive warming for the prevention of inadvertent hypothermia in patients receiving neuraxial anesthesia: A systematic review and meta-analysis of randomized controlled trials', Author Manuscript, 2018; vol 1, hh. 1-34

18. Nurul Mahmida Ariani, 'Recycle Afalan Kemasan Aluminium Foil Sebagai Koagulan Pada IPAL 'Jurnal Teknologi Proses Dan InovasiIndustri, 2017; vol 2, hh. 71-75

19. Marlinda, Ramdani, Mariana, ' Perbandingan Selimut Hangat Dengan Selimut Hangat Dilapisi Selimut Aluminium Foil Terhadap Kecepatan Kembalinya Suhu Tubuh Normal Pada Pasien Hipotermipost Sc (Sectio Caesar) Di Recovery Room Rsud Ulin Banjarmasin', Implikasi
Perawatan Paliatifpada Bidang Kesehatan, 2017, vol 8, hh. 206-212

20. Russeng, S.S., Saleh, L.M., Virani, D., Latief, A.W.L., Mallongi, A. The investigation of the lactic acid change among employee of national electrical power plan. Indian Journal of Public Health Research and Development 2018; Volume 9, Issue 1, Pages 361-365

21. Amqam, H., Thalib, D., Anwar, D., Sirajuddin, S., Mallongi, A. Human health risk assessment of heavy metals via consumption of fish from Kao Bay. Reviews on Environmental Health. 2020; https://doi.org/10.1515/reveh-2020-0023

22. Syam, A., Palutturi, S., Djafar, N., Budu, Astuti, N., Thaha, A.R. Micronutrients, academic performance and concentration of study: A literature review. International Journal of Applied Business and Economic Research, 2016; Volume 14, Issue 5, 2016, Pages 2831-2843 